\title{
The effect of neighbourhood characteristics, accessibility, home-work location, and demographics on commuting distances
}

\author{
Kevin Manaugh \\ $\mathrm{PhD}$ student \\ School of Urban Planning \& Department of \\ Civil Engineering \\ McGill University \\ Montreal, Quebec H3A 2K6 \\ Tel: 514-762-6545 \\ E-mail: kevin.manaugh@mail.mcgill.ca \\ Luis F. Miranda-Moreno, PhD \\ Assistant Professor \\ Department of Civil Engineering and \\ Applied Mechanics \\ McGill University \\ Phone: Tel: 514-398-6589 \\ E-mail: luis.miranda-moreno@mcgill.ca
}

\author{
Ahmed M. El-Geneidy, PhD \\ Assistant Professor \\ School of Urban Planning \\ McGill University \\ Montreal, Quebec H3A 2K6 \\ Tel.: 514-398-8741 \\ E-mail: ahmed.elgeneidy@mcgill.ca
}

Key Words: Commuting distance, Travel Behaviour, Neighbourhood Typology, Home-work location, modeling, accessibility measures

Please cite as Manaugh, K., Miranda-Moreno, L., \& El-Geneidy, A. (2010). Neighborhood travel behavior: A factor and cluster analysis to understand travel behavior in the Montréal metropolitan region. Transportation, 37(4), 627-646. 


\section{Abstract}

The goal of this paper is to better understand home-to-work travel distances throughout the Montréal Metropolitan region. A simultaneous equation modeling analysis is carried out to jointly explain commuter trip length and home-work location as a function of neighbourhood typologies, commuter socio-demographics and measures of job/work accessibility. First, a factor and cluster analysis of urban form is performed over the entire region on a fine-scale grid pattern. The outcome of this analysis is the classification of typologies at both home and job locations. Different measures of accessibility and commuter socio-demographics are then incorporated into the analysis. Varied data sources including a detailed Montréal Origin-Destination Survey on over 30,000 home-to-work automobile trips are analyzed. Among other results, commuters that live and work in a different sub-region almost double the average trip distance and although socio-economic factors are statistically significantly correlated with commuter distance, these factors have a marginal effect. Interestingly, our results highlight the importance of urban form and job accessibility. Deciding on whether to live and work in the same subregion was modeled as an endogenous binary random utility model; unobserved heterogeneities seem to be simultaneously influencing both the home-work location choice and trip-to-work distances. Our results underscore the importance of home-work location with respect to urban form and job accessibility. Hence, policies that support more dense and mixed land-use in suburban areas would not be enough to reduce commuter distances. These actions should be accompanied by other policy initiatives to discourage long car trips. 


\section{INTRODUCTION}

Increases in daily mobility throughout North America are a hallmark of technological progress in the transportation sector of the last century. While much of this mobility has an undoubtedly positive influence on quality of life in the form of economic opportunity, the ability to match residential and job location preferences, access to emergency care, leisure travel etc., there exists a vast array of negative externalities in the form of pollution, sprawl, congestion and social equity. Apart from the obvious adverse effects of fuel combustion, other factors such as noise, health issues related to physical inactivity, safety, and inefficient land-use are problems associated with widespread automobile use (Crane and Schweitzer 2001). It is also worth noting that while technological advances in the form of “cleaner" cars may reduce emissions from fossil fuel combustion, they will little to stem the proliferation of low-density, auto-dependent places, improve road safety, get people walking for exercise, or slow the demand for new road construction.

As the importance of understanding travel behaviour and reducing car dependency is clear, the amount of literature concerning travel outcomes and urban form factors is understandably vast. Many past efforts have investigated the effects of urban form on key transportation travel outcomes such as trip frequency, trip length, mode choice, vehicle miles travelled - (VMT), vehicle type, etc. From all of these outcomes, commuting trip distance has attracted less attention than other travel outcomes, particularly in Canada.

Although daily home-to-work trips make up only a portion of VMT, there are several sound reasons why these trips are important to focus on. Shopping and social trips are much less likely to be regular and consistent while home-to-work trips are likely to be repeated every day. Also, as Shearmur (2006) points out, the home-to-work commute often serves to structure other trips made during the day; shopping location is more likely to be influenced by the person's work location than the opposite. Therefore, a thorough understanding of work trips is absolutely vital in attempting to characterize regional travel behaviour (Miller and Ibrahim 1998).

In the literature on travel behaviour, a large body of work has investigated the relationship between trip length, urban form and socioeconomic characteristics (see, for example (Frank and Pivo 1994; Cervero and Kockelman 1997; Badoe and Miller 2000; Boarnet and Crane 2001; Ewing and Cervero 2001; Cervero 2002; Handy, Cao et al. 2005)). Some studies show that population density and distance from downtown are correlated with lower VMT for work trips (Miller and Ibrahim 1998; Badoe and Miller 2000; Boarnet and Crane 2001; Schwanen, Dieleman et al. 2001). Interestingly, Crane (2000) presents evidence that design elements such as grid-based street patterns, mixed land uses, traffic calming devices, as well as combinations of all three have been seen to both increase and decrease car trips, VMT and car modal split, this is a clear indication that these issues are still very much open for discussion. Cameron, Kenworthy et al. (2003) found that urban form factors on their own explain 85\% to $92 \%$ of the variance in private automobile use, therefore urban form can lead to a close approximation of a given region's emissions. 
While the literature on the topic is indeed vast, there are few examples for Canadian cities. One of these is Miller and Ibrahim (1998) who found that VMT increases as residences move further away from job centres and that population density works as an "intermediate" rather than a "causal" variable in explaining VMT. Vandermissen, Villeneuve et al (2003) explored the effects of changing urban form on commuting time, finding that the shift away from a monocentric form in Quebec City, was responsible for increasing commuting time. However, in spite of the importance of the topic, several issues have not been fully addressed. For instance, very few empirical studies have looked at commuting car distance and its relationship with transit accessibility indicators, geographical home-work location and urban form typologies at both home location and work destination. The issue of commuting distance and home-work location has rarely been jointly studied. In addition, few studies have used neighbourhood typologies to address the common correlation issue among many urban form attributes. In order to provide some insights to these gaps in the research, the objectives of this work are two-fold:

1. To develop an efficient factor-cluster analysis to single out and classify home locations and work destinations according to the urban form typology in a given location.

2. To study the relationship between commuter trip distances and regional home-work location, as well as the urban form typologies developed in the first objective, individual-level sociodemographic attributes and job/employer accessibility measures.

For this purpose, a large sample of 31,997 commuting trips in the Montreal region was analyzed. A simultaneous two-equation modeling approach was adopted to represent the commuter trip distance as a continuous outcome and the regional home-work location as a binary variable. This second outcome represents the decision of living and working in a different sub-region. In other words, it differentiates commuters that stay in the same sub-region from those that cross a bridge into a different sub-region. Due to the geography and road network characteristics of the Montreal region, a large amount of daily traffic is concentrated on the regional bridges; therefore understanding the commuting behaviour of those drivers that cross one of the bridges is essential for the transportation planning process and local policy definition.

This paper is structured as follows; section 2 is a literature review of past research. Section 3 is a brief description of the study area, the data and methodology used as well as the findings from the factor and cluster analysis. The next section presents the results of the statistical models. The paper will conclude with policy implications as well as directions for future research.

\section{LiterATURE REVIEW}

The importance of understanding urban form has long been understood as central to informing policy in land use and transportation. In recent years it has become even more vital to accurately and objectively describe land use and urban form as words like "sprawl", "suburban" and even "mixed use" become 
loaded with meaning and are, at times, misused. Some researchers have criticized the over-simplification of defining suburbs and sprawl (Talen 2002; Song and Knaap 2004). In an excellent introduction to many of the inherent issues at play when discussing, defining and analyzing urban form, Talen (2002) writes of the dangers of selecting variables that are "rarely neutral[...] and can be loaded with subjective meaning".

Cervero and Kockelman (1997) describe the "3Ds" of: density, diversity, and design in an important contribution to this topic. It is through these key elements, it is thought, that policy can influence travel behaviour. Many have cautioned on the over-simplification in correlating density with both mode choice and distance. Often, dense areas have a much lower median income (Crane 1996; Boarnet and Crane 2001). As well, dense urban areas are often well served by transit, have limited parking and have employment and commercial opportunities located in close proximity. Therefore simply increasing suburban residential density would have little to no effect if an effort is not made to increase transit infrastructure, mix commercial and residential land uses and limit parking. Other researchers have remarked that the share of rental dwellings and residential density both act as proxies for income. They suggest that, as many older parts of cities offer a predominantly rental market, the easy assertion that older development (pre-1945), offers better walkability is not so clear. Perhaps it is simply that more people who cannot afford a car live there (van de Coevering and Schwanen 2006). The primary concern is the issue of self-selection whereby households who enjoy walking or cycling may choose to live in areas where this is possible. This is arguably the core of the issue; do neighbourhood characteristics influence behaviour or do behaviour and preferences influence choice of neighbourhood? Handy (2005), in a quasi-longitudinal study, did find evidence for a causal relationship between changes in travel behaviour and the built environment. However, a previous study by Handy and Clifton (2001) found that self-selection largely explained the observed differences in travel behaviour. Studies that use an extensive questionnaire to capture household preferences can reveal much about attitudes and go a long way towards understanding the relationship between urban form and travel (Kitamura, Mokhtarian et al. 1997; Limtanakool, Dijst et al. 2006). Kitamura et al. (1997 p. 156), in fact conclude that "Attitudes are certainly more strongly, and perhaps more directly associated with travel than are land use characteristics". They propose that land use policies alone will have minimal affect on travel behaviour without a corresponding change in residents' attitudes.

The issue is arguably more about making these neighbourhood types more desirable for people who could otherwise "afford" to own a car and live in the suburbs. As Badoe and Miller (2000) point out, the question is whether these types of dense mixed-use neighbourhoods are under-represented in the marketplace. Another key issue concerns "trip replacement". Studies often point to the fact that residents might walk more in certain neighbourhoods for non-work purposes. While this might be a positive step for health and social reasons, if the same person has a lengthy commute at peak hours, it is debatable whether there is much improvement in overall VMT. Correlations among travel distance, car ownership and income have been widely documented. Builing and Kanaroglou (2006) conclude that many land use policy attempts to facilitate more transit use and shorter trips are often thwarted by the "tastes and 
preferences of households”. They also found, in agreement with Giuliano and Small (1993), that rising mobility in the last several decades "reduces the significance of the regional distribution of employment as a determinant of travel behaviour". They also question the degree to which minimizing commuting time plays in residential choice decisions and whether demographic factors are more likely to influence travel decisions and behaviour than land-use policy changes.

Gender has also been shown to be a major determinant in commuting travel behaviour, with males, travelling farther in daily commutes. Past research has shown that women have shorter work trips but also make more daily trips and use public transit more than men (Mauch and Taylor ; Hecht 1974; White 1986; McLafferty and Preston 1991; Sermons and Koppelman 2001). While the intuitive explanation is that women choose to work closer to home for reasons of housekeeping and childcare, some have questioned this and showed that the number and ages of children in the household have little effect on the distance that the woman is travelling in the daily commute (McLafferty and Preston 1991). However, Sermons and Koppelman (2001) found evidence that the number of children in the household has a significant effect on the difference between male and female commuting distances within the household.

Income and education have been shown to be significant factors in contributing to longer commutes. It has been hypothesized that lower income jobs have a better spatial distribution than many high income jobs. For example, retail, service and convenience stores are often somewhat evenly dispersed throughout an urban region in contrast to hospitals, universities, office towers, and suburban office parks. In other words, one might always be near a low-income job, but kilometres away from highpaying skilled employment. Guiliano and Small (1993) present evidence from Los Angeles that suggests that administrative and technical workers commute up to $40 \%$ longer than service workers. Other research suggests that certain sectors of employment, trade and transport for example, tend to be located in low-density areas along highways thereby making the modal split by car much higher for workers employed in these fields (van de Coevering and Schwanen 2006).

\section{STUDY CONTEXT AND DATA}

Montréal is among the largest cities in North America. While Montréal has a lively and economically active urban core, recent years have seen suburban sprawl extend further into the surrounding regions. Montréal has an extensive public transit system comprising bus, metro and commuter rail lines. Previous research has identified six employment sub-centers. Four are located on the island of Montréal and two off the island. While Montréal is clearly not a mono-centric city, it should be noted that the largest concentration of jobs is on the island and in the CBD in particular. Roughly 182,000 jobs are located in the CBD alone (Coffey and Shearmur 2001). Although the city still has a vibrant core, the growth at the centre has slowed recently in relation to outlying areas (Collin, Dagenais et al. 2003). According to the Communauté métropolitaine de Montréal, the region covers an area of 4,360 square kilometres and had a population of 3.6 million in 2007 with 1.4 million private dwellings, 1.84 million automobiles and 1.86 million jobs (Communauté Metropolitan de Montréal 2009). 
The City of Montréal is located on an island in the St. Lawrence River while the City of Laval is located on another island just to the north-west of Montréal. The two major "suburban" sub-regions are referred to as the Northshore and Southshore due to their general geographical relationship with the island of Montréal. This is illustrated in Fig. 1. Given that the geographical setting of the metropolitan region under analysis is divided into four sub-regions; a particular interest in this paper is devoted to the understanding of home-work location interactions between the sub-regions. A particular characteristic of the region is the large amount of automobile commuter flows between sub-regions across its bridges (and one tunnel).These trips represent almost $40 \%$ of all trips in our sample, $90 \%$ of these trips are generated in Laval, or the North and South Shores with the island of Montreal as a destination.

\section{Insert Fig. 1 here}

\subsection{Data for commuter trip distance, socioeconomcs, home-work location and accesibility}

Travel distance and commuter socioeconomics: Travel distance from home to work was obtained from the 2003 Montréal regional Origin-Destination survey (OD survey) using GIS software. The O-D survey includes disaggregate data on all trips that were made by each person in a participating household (AMT 2003). Trip characteristics: length, mode, purpose and time of departure were obtained from this dataset. Trip lengths were estimated by determining the shortest network path based on posted speed limits. This is, of course, much more accurate than simple straight-line distance or solving the network for shortest distance. Variables from the survey at the individual level include gender, age, income, and total number of personal trips. At the household level, variables include number of people per house, number of children, number of vehicles, income and total number of household trips. Summary statistics of these variables are presented in Table 1.

\section{Insert Table 1 here}

Geographic home/work location: This variable is also denoted as "bridge”. As mentioned before, given the importance of the home-work location relationship, in particular for workers traveling across subregions, a dummy variable was generated - this represents $35 \%$ of the sample. This variable differentiates commutes that stay in the same sub-region from those that cross a bridge into a different sub-region - see Fig. 1. Due to the geography and road network of the region, a large amount of daily traffic is concentrated in these corridors; therefore understanding commuters that cross one of the bridges has important implications for the planning of new transportation infrastructure and local policies. 
Job/Worker Accessibility Using Canadian Census data on worker and employment data at the census tract level, the number of jobs accessible to each home cell within 30 minutes driving time on the road network was also calculated as well as the number of workers having access to each work destination within 30 minutes driving time. This second measure acts as a proxy for worker competition. This is based on a centroid-based model where a given home location is deemed accessible to a given work location if they are located in TAZs that are within 30 minutes of one another.

\subsection{Data for factor-cluster analysis}

Based on a thorough review of previous studies, a comprehensive list of urban form variables (covering land use, employment, economics, demographics and service accessibility) was generated for every grid cell. Song and Knapp, (2004) was a key source for variable choice among others (Coffey and Shearmur 2001; Cervero 2002; Krizek 2003; Limtanakool, Dijst et al. 2006; Wilson, Krizek et al. 2007).

The goal at this stage was to compile a set of data that would explain the differences between neighbourhood types. The outcome of this analysis was the generation of the neighbourhood typology used in the modeling analysis. Summary statistics of the list of variables used for the classification of neighbourhoods is presented in Table 2.

- Land Use: The area of each of the following land uses was measured in each cell: open space, park, commercial, residential, industrial, institutional, and water. The length of train track in each cell was also measured. In addition, the total lengths of road, as well as the separate length of local roads, major roads and expressways were measured.

- Employment: This category includes variables that capture both employment and education characteristics. The number of manufacturing jobs, total number of workers, as well as the number of people who had attained a High School diploma, trade school certification or a University degree as their highest level of education was collected.

- Housing/ Demographics: Information on income and family structure was collected using Canadian Census data from 2001. This category included the variables: average household size, average number of children, average number of bedrooms, and average number of rooms. In addition, the census provided variables on the number of various dwelling types and year of construction.

- Service accessibility: This includes accessibility to downtown, commuter train/bus, restaurants and retail. Cells with their centroid within 800 network meters of a commuter station or metro were deemed to be "accessible". Other services were simply counted in the cell and surrounding cells. It is important to contrast this with the job and worker accessibility measures above. The former represent regional accessibility measures using network driving distance, this simply captures the local neighbourhood characteristics i.e. the number of services in the cell and surroundings. 
- Economics: This category examined census data in the following variables: average dwelling value, average rent and median household income.

Insert Table 2 here

\subsection{METHODOLOGY AND RESULTS OF THE FACTOR-CLUSTER ANALYSIS}

Given the correlation between many of the attributes of urban from at the neighbourhood level, a data reduction technique (factor-cluster analysis) was used to consolidate these local neighbourhood characteristics into a small set of variables. To do so, the Metropolitan region was divided into $150 \mathrm{~m} \mathrm{x}$ $150 \mathrm{~m}$ grid cells. The selection of the grid cell size was based on reviewing previous research modeling land use changes over time (Waddell 2004). Factor and cluster analysis techniques were then utilized to classify each grid cell to be part of a certain neighbourhood type using variables defined in Table 1 . This classification took into account the neighbourhood characteristics in the cell as well as the cells adjacent to it.

Given the large quantity of variables, the use of factor analysis is justified. This technique works to extract a smaller number of factors from a large data set, while keeping the meaning and significance of the full data set. The analysis presented is a separate Factor and Cluster analysis on Home and Work locations. In this way, the 19000 grid cells that are home to a traveler of which data is available from the O-D survey and the 9200 cells that represent work locations were analyzed separately. A different set of variables were shown to be significant for each process resulting in an output that clearly shows differences between residential and work-place locations throughout the region.

\section{Neighbourhood Typologies (Clusters) for home locations}

The first Factor analysis looked at the 19,879 residential cells in which home to work travel is known. From an initial inputting of over 100 variables at the grid cell and neighbouring cell level, 67 variables were shown to significantly explain variations in neighbourhood types. This includes 33 variables at the grid cell and neighbouring cells plus distance from downtown. From this, 15 factors were extracted that jointly explain over $80 \%$ of the variation between cells.

Once the factor analysis was done, a cluster analysis was carried out. The goal of using cluster analysis is to further refine the neighbourhood types regardless of spatial location (Song and Knaap 2004). Kmeans cluster analysis facilitates this by sorting each cell into one of a pre-determined number of clusters such that internal similarity is maximized while similarities between groups are minimized. The optimal number of cluster categories extracted from the fifteen factors was found to be ten. Although this resulted in one very small cluster (10 cells), the overall effectiveness of this analysis far outweighed 
the use of nine or fewer factors. This small cluster was subsequently dropped from the analysis. Other amounts were found to not adequately describe differences in urban form. Local knowledge of the region was useful in understanding the clusters as is often the case in this type of analysis.

Each Cluster ${ }^{1}$ has - positive or negative - inputs from each factor; these are then used to understand the characteristics of the cluster. Below are the names and a brief description of each cluster:

$1 \quad$ Park areas. The factor capturing park land and golf course is by far the biggest contributor to this cluster, however, the second highest input capturing new construction helps make sense of this group, newer residential areas fronting on parkland.

2 “Big Box Commercial”. With one factor overshadowing all others, this cluster is relatively easy to interpret. Noteworthy absences include retail and highway, this helps to differentiate it from commercial streets with a higher concentration of small-scale shops and good accessibility to transit.

3 High Density Residential. Characterized by population density and smaller household size, perhaps most importantly it is negative in retail and services, differentiating itself from the urban mixed use category below.

4 Commuter Train Access. This cluster corresponds with residential areas with high accessibility to the commuter train system.

$5 \quad$ Single Family Residential. This is clearly single family homes with poor retail access. Not surprisingly, this is the largest of the ten clusters, comprising roughly half of the residential clusters. While they do tend to be farther away from downtown on average, there is a wide dispersion of these cells both on and off the island.

6 This cluster is characterized by proximity to highways and retail services.

7 Commercial Streets. Here the mapped output was quite helpful in defining the cluster. It corresponds with Montréal’s main commercial streets such as St-Laurent and St-Denis.

8 This cluster describes waterfront property throughout the region.

9 Urban mixed use. While 4, 8, and 10 share many of the same factor contributions, their relative factor loadings make their differences clear. This cluster is dominated by high density residential with retail services nearby.

\section{Neighbourhood typologies (clusters) for work locations}

\footnotetext{
${ }^{1}$ Clusters and typologies are used interchangeably in the text.
} 
While the same variables were initially inputted, the process for the work locations showed different variables to be significant in explaining the variation between cells. The work location factor and cluster analysis includes thirty-six variables at both levels plus distance from downtown. As with the residential analysis, fifteen factors were extracted from the factor analysis.

$1 \quad$ Isolated Suburban Retail areas. With high positive inputs from the park land use as well as the factor capturing both high levels of both retail and profesional employment, this cluster describes relatively isolated areas of employment in otherwise park or open space.

2 Waterfront. The measurement of water is by far the biggest factor in this cluster, a high score for highway makes this cluster job areas near highways and water.

$3 \quad$ Mixed Use Commercial and Residential.

$4 \quad$ Suburban office parks. Isolated Retail and Commercial areas near parks and golf, with higher input from the professional and retail job concentrations.

5 "Suburban" areas. Although this cluster is negative in all factors that capture employment and services, there are obviously some employment oppurtunities, as each cell is the destination of a work trip.

6 “Big Box Commercial” characterized by commercial land use near major roads, with positive, but small, inputs of employment.

$7 \quad$ High density residential mixed use, similar inputs to Mixed Use Commercial, however there is more residential presence.

8 With the highest loading from the train accessibility factors, this cluster is labelled Train.

$9 \quad$ Instititutional and Government Job areas.

10 Its four postive inputs suggest, Employment Subcenters easily accessible by highway.

Fifty-four percent of all work cells are located on the island, roughly $9 \%$ in Laval, with the remaining $37 \%$ split roughly evenly between the North and South shores.

The final output of the factor-cluster analysis was the classification of each single origin and destination into the previously defined clusters. The distribution of origins and destinations among these clusters is provided in Table 3. This table shows that for instance, around seventeen thousand trips (more than $50 \%$ ) are generated in single-family neighbourhoods.

\section{Insert Table 3 here}

\section{STATISTICAL MODELING ANALYSIS}


After the factor and cluster analysis and data assembly, an exploratory analysis was conducted to identify high correlations between the different explanatory variables. A correlation matrix was generated from which very low correlations among variables were observed. This exercise validated the usefulness of our factor-cluster analysis. By characterizing the origin and destination of home and work locations, one eliminates the high level of correlation between the urban form attributes which is a common problem that makes it difficult to precisely identify the effect of each urban form variable.

A modeling regression analysis was the next step. Again, the objective was to identify the factors associated with commuting distance including geographical home-work location as a dummy variable as well as the individual socio-economic characteristics, neighbourhood types and accessibility as explanatory variables. For this purpose, two different modeling approaches were used: a standard regression analysis and a two-equation simultaneous approach to account for the potential problem of endogeneity. As illustrated in Figure 2, the decision of commuter distance and living and working in a different sub-region should be jointly affected by both observed attributes (e.g. socio-demographics) and unobserved factors. This assumes that the decision of living and working in a different sub-region is taken jointly with the commuter travel distance. This hypothesis is related to the widely debated issue of residential endogenous choice location. It is plausible that travel commuter behaviour is correlated with socio-demographics characteristics and unobserved factors (e.g., life style, environmental concerns, perception of risk concerned with accidents on roads, etc.). These unobserved factors are then affecting both car travel distance and home-work location choice. Not accounting for endogeneity may bias model estimates leading to misleading conclusions.

In the first approach, a standard regression (OLS) model was used to represent the length of trip $\left(d_{i}\right)$ as the dependent continuous variable and a logistic regression to model the home-home location. In the second approach, a two-equation simultaneous model is developed in which the first equation represents the trip length $\left(d_{i}\right)$ as a continuous endogenous variable and the second equation is a binary random utility model estimated with regional home-work location $\left(z_{i}\right)$ as an endogenous variable. In this second equation, socioeconomics $-\boldsymbol{w}_{\boldsymbol{i}}-$, at the individual level are used as exogenous explanatory variables One might suspect that middle-income workers with children, looking for space, and with access to a car would be more likely to commute longer distances (crossing a bridge every day to work).

In a form of equation, the two-equation model can be written as:

$$
\begin{aligned}
& d_{i}=\boldsymbol{x}_{\boldsymbol{i}}^{\prime} \beta+\gamma \cdot z_{i}+\varepsilon_{i} \\
& z_{i}^{*}=\boldsymbol{w}_{\boldsymbol{i}}^{\prime} \gamma+v_{\boldsymbol{i}}
\end{aligned}
$$

And the geographical work-location decision for respondent $\mathrm{i}$ is:

$$
z_{i}=1 \text { if } z_{i}^{*}>0 \text {, and } 0 \text { otherwise }{ }^{2} .
$$

\footnotetext{
${ }^{2}$ When home and work locations are in the same region
} 
Where, $\boldsymbol{x}_{\boldsymbol{i}}$ and $\boldsymbol{w}_{\boldsymbol{i}}$ are vectors of independent variables (socio-demographics, accessibility measures, neighborhood typologies, etc.) - these vectors can contain similar variables. Moreover, $\varepsilon_{i}$ an $v_{i}$ are the random components in each equation which are assumed to follow a bivariate normal distribution with mean zero and covariance matrix given by, $\left[\begin{array}{ll}\sigma & \rho \\ \rho & 1\end{array}\right]$. Also, $\beta$ and $\gamma$ are a vector of regression parameters to be estimated from the data. For model calibration, a standard regression modeling approach using OLS estimator is used in the simple approach and a treatment effect model using a full maximum likelihood (FML) estimator is used for the simultaneous modeling approach (these two estimators are standard features in STATA).

\section{Results}

The results of three different modeling outputs are presented in Table 4. The models presented in this table are:

i. Base model: An OLS basic model that only looks at the socio-economic information of the individual - note that from this result, a very low R-square $(0.06)$ is obtained meaning that sociodemographics at the individual and household level explain very little of the trip length variability.

ii. $\quad$ Expanded model: An OLS-extended model including dummy variables for each home and work cluster, measures of accessibility to jobs and employees and regional home-work location. The expanded model performs much better and gives important insight into regional travel behaviour. The increase in the R-square - from .06 to 0.40 - resulting from the addition of the clusters and "bridge" dummy ${ }^{3}\left(z_{i}\right)$ shows the importance of using these non-demographic variables.

iii. Simultaneous equation model: This model is a FML two-equation model accounting for the potential location endogenous switching. Here, the decision of living and working in a different sub-region (crossing a bridge) is modeled as a dummy and expressed as a function of sociodemographics including number of vehicles, presence of children, income, young-adult dummy (adults between 25-45 years old), and male dummy ${ }^{4}$. As we can see at the bottom of Table 3 , the size of the bias $(\rho=0.1)$ is significant at the $5 \%$ level. ${ }^{5}$ This means that the regional home-work location decision is influenced not only by those mentioned observed factors but also unobserved heterogeneities that jointly influence both trip length and location choice (endogeneity problem exists). From the same parameter, we can also observe that since $\rho$ is negative, the OLS underestimates the location choice effect. We can then conclude that our conjecture that the OLS parameter estimates were biased is verified; however, this bias seems to be small-to-moderate in most of the parameters. One of the main differences is for the "bridge" dummy variable. In this case, the bridge parameter is equal to 11,622 and 12,774 when using the standard and

\footnotetext{
${ }^{3}$ Bridge stands for the dummy variable differentiating between commutes that travel across a bridge into a different sub-region.

${ }^{4}$ Other set of variable combinations were attempted - only the best outcome is reported.

${ }^{5}$ According to the likelihood ratio test (with a chi-square value of 6.1), we then reject the null hypothesis that the two error terms are uncorrelated.
} 
simultaneous equation approach, respectively. This means that the use of OLS produces a significant underestimated value of more than one-km.

\section{Insert Table 4 here}

According to Table 4 and given that the simultaneous model provides slightly more reliable parameter estimates, the interpretation of the results is provided according to its outcome as follows:

- The significance and magnitude of the endogenous bridge dummy is very important. Commuters that stay in one sub-region are significantly shorter. While this is somewhat intuitive, it is important to point out the each sub-region is quite large; the island is roughly 51 network km from tip to tip. In addition, the North and South Shore regions are each larger than the island of Montreal. Commutes that cross sub-regions are $12.8 \mathrm{~km}$ longer than those that stay in one region. As these trips are quite common and contribute to VMT in an important way, they will be dealt with in more detail below.

- From the socioeconomic variables, age, income dummies and total number of trips per day by individual were all statistically significant with a negative coefficient. For instance, a lowincome worker travels by car at least $1.0 \mathrm{~km}$ per day less than a high-income worker. As expected, commuting distance declines with age. In addition, the AM peak dummy sign was also negative, suggesting that the AM peak congestion may have an effect on departure times; however, its effect is not statistically significant.

- The variables number of cars, gender, income and full-time status were all positive. For instance, wealthy males working full-time generate trips that are around $3.7 \mathrm{~km}$ longer than those car trips of low-income women with a part-time job. This result is in accordance with previous work (Mauch and Taylor ; White 1986; McLafferty and Preston 1991; Limtanakool, Dijst et al. 2006).

- Turning our attention to the home typologies, the neighbourhood clusters of single family, train, water front and urban mixed use are shown to be significant with a positive sign with respect to the reference dummy variable that is high-density residential origin. In addition, the origins of commercial streets and big box areas are significant respectively. The distance added is noteworthy. For example, commutes from waterfront, train, single family origins are 3.2, $2.1 \mathrm{~km}$ and $1.8 \mathrm{~km}$ longer than high-density residential respectively.

- Looking at the work (destination) typologies, the destination clusters of waterfront, new highdensity, train, institutional and job centres are all associated with longer work trips. However, the effect on trip length is not as strong as the origin clusters. For example, institutional and jobcentre destinations are shown to increase trip length by only roughly 1.2 and $1.4 \mathrm{~km}$, 
respectively. Intuitively, this suggests that the origin of a work trip plays a more important role in determining trip length than characteristics of urban form at work destinations. This brings up the importance of understanding residential choice in discussions of commuting length.

- Some interesting outcomes were also found for both suburban and high density residential mixed use areas. While single-family origins generate much longer trips, suburban destinations are not shown to be associated with longer commutes. Most noteworthy is the fact that the average length of car trips to high density areas is actually longer than the average car trip to a suburban location. These findings are similar to Barbonne’s work (Barbonne 2008), however this study looks not just at one neighbourhood but on a particular type of neighbourhood that is scattered across the region. While this is in some ways obvious, after all, these areas are more attractive to workers; it does contribute to understanding of how these high density areas are contributing to overall regional mobility. While local residents might be working locally, this particular urban form is leading to a large amount of regional VMT. Also noteworthy is the fact that the average distance of single-family to suburbs is well below the average distance of all home-to-work car trips of $14 \mathrm{~km}$.

- The measures of regional job and employee accessibility perform as expected. Access to jobs is negatively correlated to trip lengths and access to employees at the point of destination is positively correlated. This highlights the importance of commuter competitiveness. This is also similar to the work of Vandermissen et al (2003) examining the determinants of commuting distance over time in Quebec City.

- From the regional home-work location model, it is clear that middle-class middle-age males with children (less than 5 years) have a higher change to live and work in a different sub-region. In addition, the presence of endogeneity is confirmed meaning that unobserved factors (e.g. personal attitudes and life style) may influence simultaneously both the location decision and travel distance. ${ }^{6}$ Although some workers are obliged to travel long distances to get to work, many others have chosen to live and work in different sub-regions driving considerable distances. However, these commuters perhaps decide to travel longer distance not because they like driving, but because they look for larger spaces, better housing prices and/or a certain lifestyle, which in turn influences both their location decision and travel behaviour.

\section{Policy implications}

\footnotetext{
${ }^{6}$ Again, despite the fact that the two modeling outcomes are similar, for some particular parameter estimates the differences are significantly different, such as the endogenous "bridge” variable which is under-estimated with the OLS. For other variables, such as male, car ownership and income the effects are over-estimated.
} 
Car commutes crossing bridges to the island of Montreal (living and working in a different sub-region) are usually the longest trips in the region. This has several implications: These trips contribute a higher amount of pollution based on their VMT, but, because they are forced to go over one of fourteen bridges, are also responsible for increased congestion. These reasons would support the - contentious idea that bridge tolls should be implemented, that transit should increase its regional offerings and that higher concentrations of employment opportunities should be encouraged in some suburban locations.

Suburb-to-Suburb commuting is both quite prevalent and predominantly car dominated, however it is far from the longest commute in the region. In contrast to the single-family-to-suburban travel, most car trips that originate from single-family areas or go to job centres are much longer than other trips. This also seems to confirm the usefulness of having a better mix of jobs and residences in the suburbs.

Many assumptions are upheld in this analysis, residents of dense mixed-use travel shorter distances by "better" modes of transportation. However, these areas also bring in travelers from long distances, including many by car. Of special interest is the dissonance between trips in and out of certain types of areas. In particular, the fact that while commutes from high density residential are shown to be shorter and less car-centric, many of the commutes into high density areas are, in fact, longer than the regional average. This again points to the usefulness of more "suburban" job offerings and disincentives to driving: congestion pricing, bridge tolls, parking policy, etc.

"Suburban type development" is more spread out spatially than often thought. The geographical spatial distribution of clusters is noteworthy in its own right and gives a nuanced picture of regional home and work locations. Since it is found that both location and travel distances are affected by common underlying factors and/or attitudes, neighbourhood attributes would not change commuter travel behaviours alone. It would seem that in addition to the many options already suggested to combat caruse, that some psychological and behavioural strategies such as marketing on public transport, travel campaigns, and travel education, might have some success - e.g., see Fujii et al. (Fujii and Taniguchi 2005). In addition, as Kitamura et al. (Kitamura, Mokhtarian et al. 1997) proposed , a thorough understanding of how travel attitudes are formed, how they relate to residential and workplace location decisions and vehicle acquisition decisions and lastly, how they can be altered by land use policy is absolutely vital in any discussion of travel behaviour. An interesting body of literature has also examined how certain character traits of urbanites might vary from suburbanites leading to residential choice decisions (Prevedouros 1992).

Interestingly, the city of Montreal has recently implemented an advertising campaign entitled "A life near everything" designed to show the value of living in central neighbourhoods and downtown, particularly for young families (Montreal 2009). With slogans such as "Don’t put a bridge between you and your family" and "Local stores are better when they are actually local." these signs can be seen at Metro stations and highways. While it is much too early to determine if this will have any effect on residential choice and travel behaviour, it is interesting that a municipality is taking this approach. 


\section{CONCLUSIONS}

This paper investigates the heterogeneities of trip-to-work distance and its association to urban form, home-work location, individual socioeconomics and measure of accessibility. To do so, two models, a standard OLS and a simultaneous equation model were developed. This last model accounts for the presence of endogeneity in the home-work location decision.

Given the correlation between many of the attributes of urban from at the neighbourhood level, this paper proposes a useful and easy way to characterize urban form for thousands of home and work locations throughout the region of Montréal using factor and cluster analysis. We showed how the proposed factor-cluster approach is useful to consolidate local neighbourhood characteristics into a small set of variables.

As hypothesised, it was found that unobserved factors (e.g. personal attitudes and life style) influence simultaneously both the home-work location and travel distance. It seems that commuters driving longer distance look for larger house spaces at better price and/or certain life-style, which in turn influences both their location decision and their travel behaviour. Our result provides some additional empirical evidences to the widely debated issue of residential location choice and its impact on car use.

Although commuter travel behaviour has attracted a lot of attention in the literature, more research is needed. Using a simultaneous equation modeling approach and longitudinal data, these findings will be further explored in future research.

\section{Acknowledgments}

The authors acknowledge the financial support of the NSERC Discovery Grant. Special thanks also goes to AMT for providing access to the Montréal Origin-Destination used in this analysis and the MTQ, who provided regional travel times. Assumpta Cerda prepared the regional accessibility measures. All errors and the views expressed in this research, however, are solely ours. 


\section{REFERENCES}

AMT (2003). Fichier de déplacements des personnes dans la région de Montréal Enquête OrigineDestination 2003, version 03.b période automne.

Badoe, D. A. and E. J. Miller (2000). "Transportation-land-use interaction: empirical findings in North America, and their implications for modeling." Transportation Research Part D 5: 235-263.

Barbonne, R. (2008). "Gentrification, nouvel urbannisme et évolution de la mobilité quotidienne: vers un développement plus durable? le cas du Plateau Mont-Royal (1998-2003)." Recherches sociographiques 49(3): 423-445.

Boarnet, M. and R. Crane (2001). "The influence of land useon travel behavior: specification and estimation strategies." Transportation Research Part A 35: 823-845.

Buliung, R. N. and P. S. Kanaroglou (2006). "Urban form and household activity-travel behavior." Growth and Change 37(2): 172-199.

Cameron, I., J. R. Kenworthy, et al. (2003). "Understanding and predicting private motorised urban mobility." Transportation Research Part D 8: 267-283.

Cervero, R. (2002). "Built environment and mode choice: toward a normative framework." Transportation Research Part D 7: 265-284.

Cervero, R. and K. Kockelman (1997). "Travel demand and the 3D's: Density, diversity, and design." Transportation Research Part D 2(3): 199-219.

Coffey, W. J. and R. G. Shearmur (2001). "The identification of employment centres in Canadian areas: the example of Montreal, 1996." The Canadian Geographer 45(3): 371-386.

Collin, J.-P., M. Dagenais, et al. (2003). "From city to city-region: Historical perspective on the contentious definition of the Montréal Metropolitan area." Canadian Journal of Urban Research 12(1): 16-34.

Communauté Metropolitan de Montréal. (2009). "Statistics." Retrieved 24/02/09, 2009, from http://www.cmm.qc.ca/index.php?id=334.

Crane, R. (1996). "On form versus function: Will the new urbanism reduce traffic, or increase it " Journal of Planning Education and Research 15: 117-126.

Crane, R. (2000). "The influence of urban form on travel: An interpretive review." Journal of Planning Literature 15(3): 3-23.

Crane, R. and L. Schweitzer (2001). "Transport and sustainability: The role of the built environment." Built Environment 29(3): 238-252.

Ewing, R. and R. Cervero (2001). "Travel and the built environment." Transportation Research Record: 87113.

Frank, L. D. and G. Pivo (1994). "Impacts of mixed use and density on utilization of three modes of travel: singlr occupant vehicle, transit, and walking." Transportation Research Record.

Fujii, S. and A. Taniguchi (2005). "Reducing family car use by providing travel advice or requesting behavioural plans: An experimental analysis of travel feedback programs." Transportation Reearch Part D 10: 385-393.

Giuliano, G. and K. Small (1993). "Is the journey to work explained by urban structure?" Urban Studies 30: 1485-1500.

Handy, S., X. Cao, et al. (2005). "Correlation or causality between the built environment and travel behavior? Evidence from Northern California." Transportation Research Part D 10: 427-444.

Hecht, A. (1974). "The journey-to-work distance in relation to the socio-economic characteristics of workers." Canadian Geographer XVIII(4): 367-378.

Kitamura, R., P. Mokhtarian, et al. (1997). "A micro-analysis of land use and travel in five neighborhoods in the San Francisco Bay area." Transportation 24: 125-158.

Krizek, K. J. (2003). "Residential relocation and changes in urban travel." Journal of the American Planning Association 69(3): 265-281. 
Limtanakool, N., M. Dijst, et al. (2006). "The influence of socioeconomic characteristics, land use and travel time in consideration on mod choice for medium- and longer-distance trips." Journal of Transport Geography 14: 327-341.

Mauch, M. and B. D. Taylor "Gender, race, and travel behavior: Analysis of household-serving travel and commuting in the San Francisco Bay Area." Transportation Research Record 1607: 147-153.

McLafferty, S. and V. Preston (1991). "Gender, race, and commuting among service sector workers." Professional Geographer 43(1): 1-15.

Miller, E. and A. Ibrahim (1998). "Urban form and vehicular travel: some empirical findings." Transportation Research Record 1617: 18-27.

Montreal, V. d. (2009). "Une vie proche de tout." 2009, from http://ville.montreal.qc.ca/portal/page? pageid=4977,43881558\& dad=portal\& schema=PORTAL.

Prevedouros, P. D. (1992). "Associations of personality characteristics with transport and residence location decisions." Transportation Research 26A(5): 381-391.

Schwanen, T., F. M. Dieleman, et al. (2001). "Travel behaviour in Dutch monocentric and policentric urban systems." Journal of Transport Geography 9: 173-186.

Sermons, M. W. and F. S. Koppelman (2001). "Representing the differences between female and male commute behavior in residential location choice models." Journal of Transport Geography 9: 101110.

Shearmur, R. G. (2006). "Travel from home: An economic geography of commuting distances in Montréal." Urban Geography 27(4): 330-359.

Song, Y. and G. J. Knaap (2004) "Internally connected, no commercial, with a touch of open space: The neighbourhoods of new homes in the Portland Metropolitan Area." Volume, DOI:

Talen, E. (2002). Measurement Issues in smart growth research. Smart Growth and New Urbanism Conference. University of Maryland.

van de Coevering, P. and T. Schwanen (2006). "Re-evaluating the impact of urban form on travel patterns in Europe and North America." Transport Policy 13: 229-239.

Vandersmissen, M.-H., P. Villeneuve, et al. (2003). "Analyzing changes in urban form and commuting time." The Professional Geographer 55(4): 446-463.

Waddell, P. (2004). "UrbanSim: Modeling urban development for land use, transportation and environmental planning."

White, M. J. (1986). "Sex differences in urban commuting patterns." The American Economic Review 76(2): 368-372.

Wilson, R., K. J. Krizek, et al. (2007). Examining the consistency of preferences about travel and neighbourhood characteristics in residential location decisions. 86th Annual Meeting of the Transportation Research Board. Washington D.C. 
List of Tables and Figures

Figure 1 The Four Sub-Regions in the Study Area

Figure 2 Schematic Diagram of Simultaneous Equation Modeling

Table 1 Descriptive Statistics for distance, home-work location and socioeconomics

Table 2 Descriptive Statistics for all variables included in the Factor and Cluster Analysis

Table 3 Frequencies of cluster-to-cluster trips

Table 4 Models for trip-to-work distance 
Figure 1 The Four Sub-Regions in the Study Area

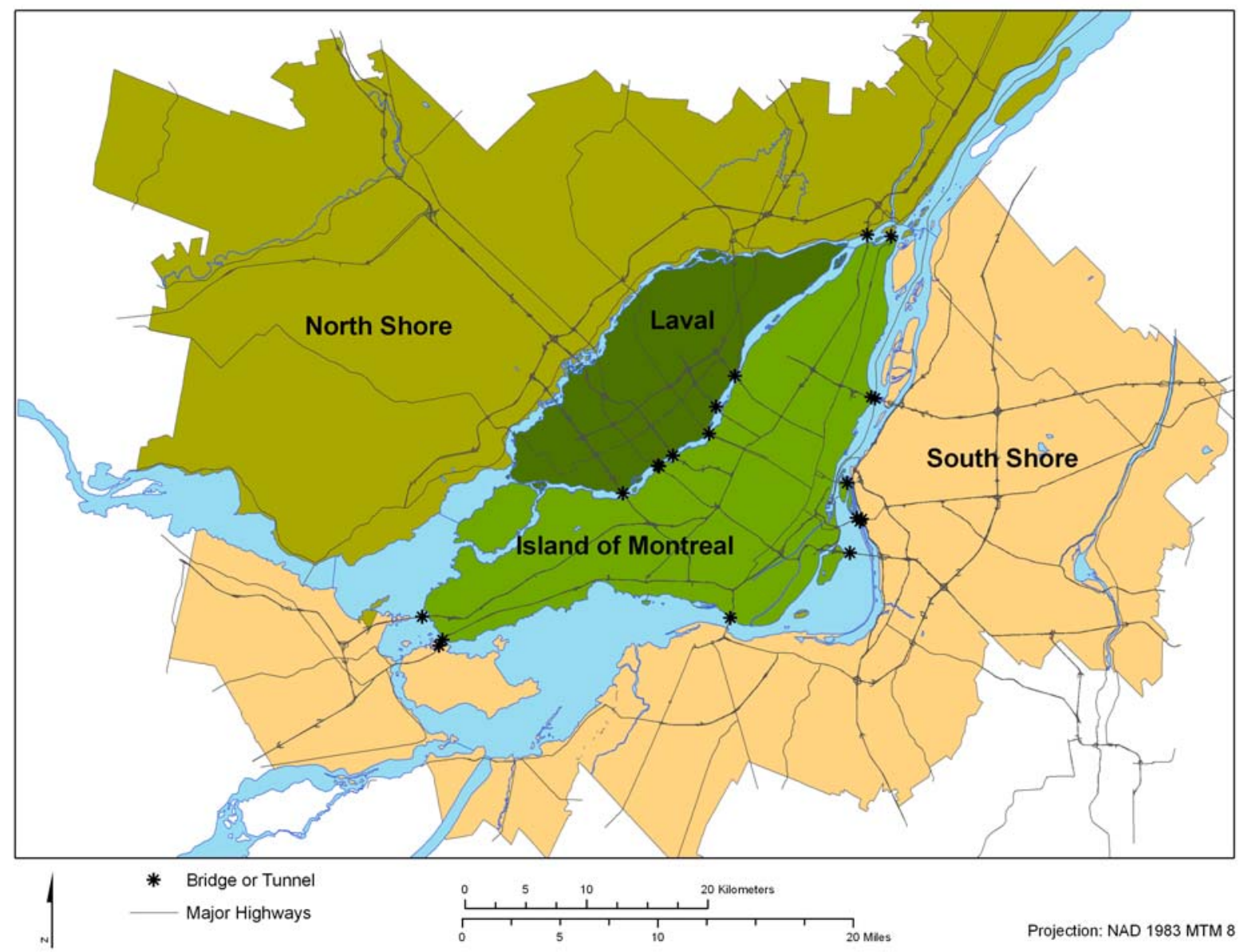


Fig. 2 A simultaneous two-equation model of the relationship between commuting distance and home-work location (crossing a bridge)

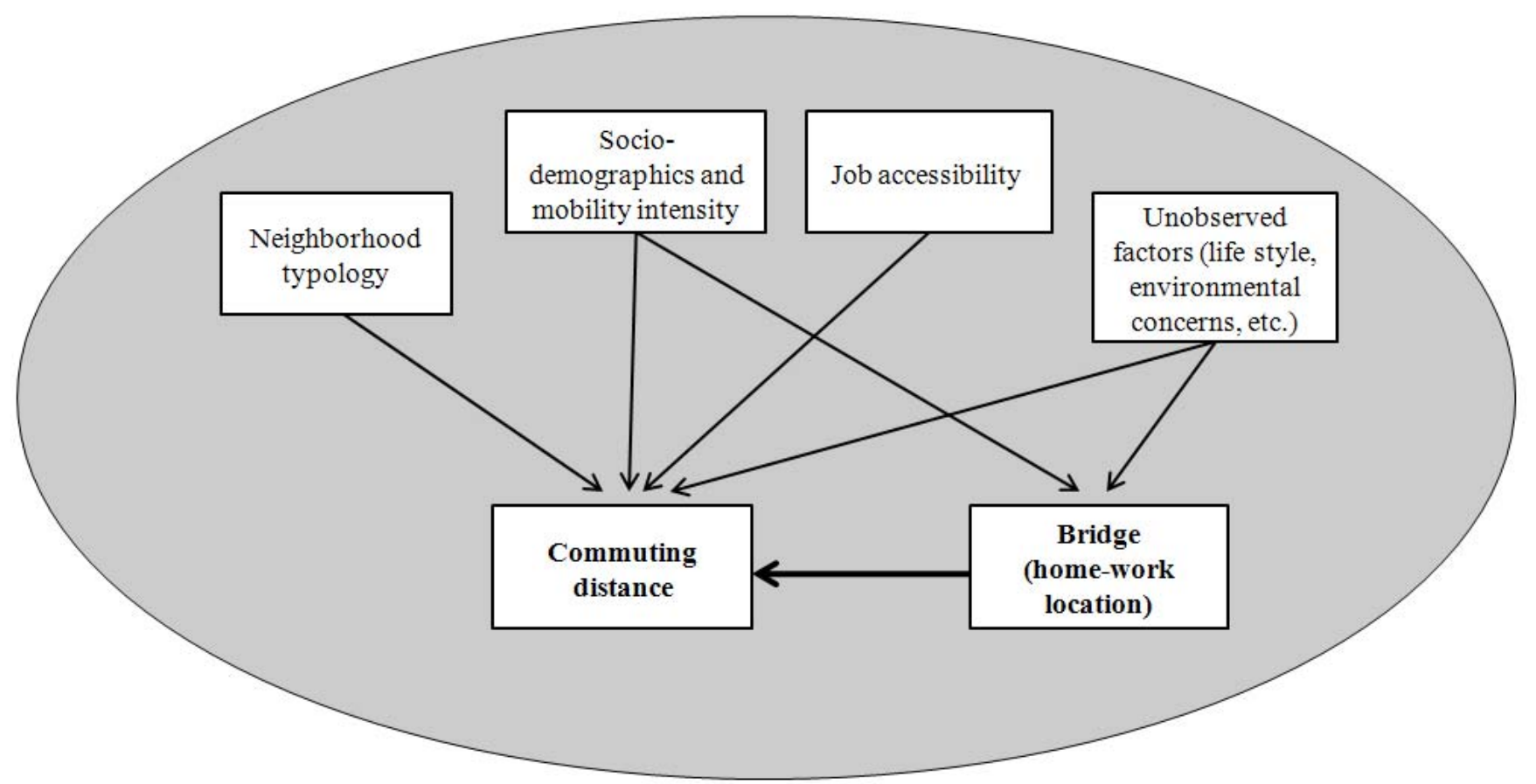


Table 1 - Descriptive Statistics for distance, home-work location and socioeconomics

\begin{tabular}{|l|cccc|}
\hline Variable & Mean & Std. Dev. & Min & Max \\
\hline Commuting distance & 14.52 & 11.48 & 0.10 & 88.69 \\
Bridge & 0.35 & 0.48 & 0.00 & 1.00 \\
Number of Vehicles & 1.83 & 0.84 & 0.00 & 8.00 \\
People & 2.92 & 1.24 & 1.00 & 10.00 \\
Children (dummy, $\leq 5$ years old) & 0.13 & 0.34 & 0.00 & 1.00 \\
Male Dummy & 0.57 & 0.50 & 0.00 & 1.00 \\
Age & 41.65 & 11.48 & 17.00 & 75.00 \\
Low Income Dummy & 0.20 & 0.40 & 0.00 & 1.00 \\
Medium Income Dummy* & 0.37 & 0.48 & 0.00 & 1.00 \\
Full time & 0.89 & 0.31 & 0.00 & 1.00 \\
AM Peak Dummy** & 0.65 & 0.48 & 0.00 & 1.00 \\
Number of daily trips & 2.84 & 1.43 & 2.00 & 21.00 \\
\hline
\end{tabular}

Number of Observations $=31,977$

* Medium Income $($ Household $)=$ Between $\$ 40,000-\$ 80,000$

**AM Peak = between 6:00-9:00AM 
Table 2 - Descriptive Statistics for all variables included in the Factor and Cluster Analysis

\begin{tabular}{|c|c|c|c|c|c|c|c|}
\hline & Variable & Source & Unit & Min & Max & Mean & $\begin{array}{l}\text { Std. } \\
\text { Dev }\end{array}$ \\
\hline \multirow{7}{*}{ 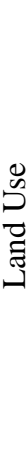 } & Commercial & DMTI & Percent of Cell & 0 & 99.2 & 1.7 & 7.8 \\
\hline & Commercial Land Use & DMTI & Square m (thousands) & 0 & 440.0 & 3.6 & 22.9 \\
\hline & Park Area & DMTI & Percent of Cell & 0 & 100.0 & 3.4 & 11.7 \\
\hline & Government and Institutional & DMTI & Percent of Cell & 0 & 100.0 & 3.6 & 12.5 \\
\hline & Industrial and Resource & DMTI & Percent of Cell & 0 & 100.0 & 6.4 & 16.9 \\
\hline & Water & DMTI & Percent of Cell & 0 & 95.7 & 0.8 & 5.7 \\
\hline & Golf area & DMTI & Square m (thousands) & 0 & 22.5 & 0.05 & 0.8 \\
\hline & Length of train tracks & STM & Metres & 0 & 1171.4 & 5.9 & 52.2 \\
\hline & Length of Highway & DMTI & Metres & 0 & 949.7 & 14.2 & 61.9 \\
\hline \multirow{5}{*}{ 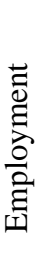 } & Manufacturing Jobs & Stats Can & Count & 0 & 9.0 & 0.2 & 0.6 \\
\hline & Number of Workers & Stats Can & Count & 0 & 611.1 & 51.4 & 47.9 \\
\hline & Unemployed & Stats Can & Count & 0 & 167.6 & 4.6 & 7.0 \\
\hline & University degree & Stats Can & Count & 0 & 747.6 & 21.6 & 33.0 \\
\hline & High school Graduate & Stats Can & Count & 0 & 240.7 & 12.2 & 11.2 \\
\hline \multirow{12}{*}{ 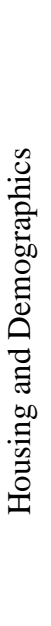 } & Trade school & Stats Can & Count & 0 & 100.3 & 7.5 & 6.6 \\
\hline & Total Population & Stats Can & Count & 0 & 1164.7 & 106.3 & 101.8 \\
\hline & Number of Dwellings & Stats Can & Count & 0 & 900.9 & 45.8 & 51.8 \\
\hline & New Construction & Stats Can & Count & 0 & 37.2 & 1.5 & 2.3 \\
\hline & Pre-46 Dwellings & Stats Can & Count & 0 & 412.7 & 7.7 & 20.9 \\
\hline & Apartments & Stats Can & Count & 0 & 910.4 & 31.5 & 53.2 \\
\hline & Owner Occupied Dwellings & Stats Can & Count & 0 & 462.1 & 19.6 & 13.0 \\
\hline & Rented Dwellings & Stats Can & Count & 0 & 873.7 & 26.1 & 44.3 \\
\hline & Average Number of Bedrooms & Stats Can & Count & 0 & 4.2 & 2.5 & 0.6 \\
\hline & Average Number of Rooms & Stats Can & Count & 0 & 10.2 & 6.0 & 1.3 \\
\hline & Average Number of Children & Stats Can & Count & 0 & 2.4 & 1.1 & 0.2 \\
\hline & Average People per Household & Stats Can & Count & 0 & 3.9 & 2.9 & 0.4 \\
\hline \multirow{4}{*}{ 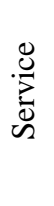 } & Distance from Downtown & NA & $\mathrm{Km}$ & 0.335 & 63.0 & 17.8 & 10.8 \\
\hline & Access to Commuter Train & STM & Dummy & 0 & 1.0 & 0.1 & 0.2 \\
\hline & Restaurants & DMTI & Count & 0 & 9.0 & 0.1 & 0.6 \\
\hline & Retail & DMTI & Count & 0 & 9.0 & 0.1 & 0.8 \\
\hline \multirow{3}{*}{ 㝘 } & Average Dwelling Value++ & Stats Can & CAD (thousands) & 0 & 1493.6 & 241.6 & 108.0 \\
\hline & Average Rent & Stats Can & CAD & 0 & 1468.0 & 584.5 & 159.9 \\
\hline & Median Household Income & Stats Can & CAD (thousands) & 0 & 234.5 & 59.4 & 19.6 \\
\hline
\end{tabular}


Table 3 - Frequencies of cluster-to-cluster trips

\begin{tabular}{|c|c|c|c|c|c|c|c|c|c|c|c|c|}
\hline & 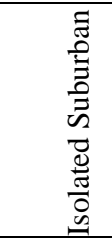 & 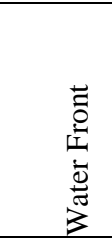 & 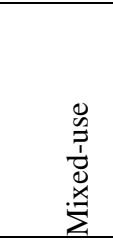 & 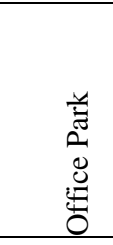 & $\begin{array}{l}\text { 咢 } \\
\text { 言 } \\
\text { के }\end{array}$ & 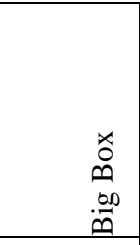 & 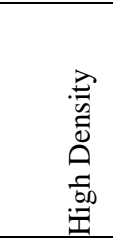 & 窇 & 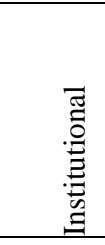 & 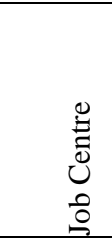 & Total & $\%$ \\
\hline Park & 1 & 1 & 8 & 0 & 37 & 18 & 9 & 35 & 19 & 49 & 177 & $0.6 \%$ \\
\hline Big Box & 0 & 3 & 17 & 0 & 141 & 55 & 52 & 54 & 58 & 159 & 539 & $1.7 \%$ \\
\hline Train & 3 & 3 & 18 & 1 & 104 & 30 & 61 & 85 & 79 & 150 & 534 & $1.7 \%$ \\
\hline $\begin{array}{l}\text { High Density } \\
\text { Res }\end{array}$ & 15 & 93 & 423 & 10 & 1746 & 616 & 1212 & 1120 & 973 & 2374 & 8582 & $26.8 \%$ \\
\hline Single Family & 42 & 273 & 520 & 70 & 4831 & 1449 & 1146 & 1813 & 1841 & 5573 & 17558 & $54.9 \%$ \\
\hline Highway & 2 & 27 & 55 & 3 & 418 & 113 & 144 & 155 & 140 & 485 & 1542 & $4.8 \%$ \\
\hline $\begin{array}{l}\text { Commercial } \\
\text { Streets }\end{array}$ & 1 & 12 & 57 & 0 & 129 & 48 & 114 & 97 & 85 & 180 & 723 & $2.3 \%$ \\
\hline Water Front & 2 & 22 & 16 & 1 & 176 & 43 & 35 & 60 & 57 & 163 & 575 & $1.8 \%$ \\
\hline $\begin{array}{l}\text { Urban Mixed- } \\
\text { Use }\end{array}$ & 0 & 19 & 137 & 0 & 256 & 81 & 365 & 237 & 227 & 445 & 1767 & $5.5 \%$ \\
\hline $\begin{array}{l}\text { Total } \\
\%\end{array}$ & $\begin{array}{r}66 \\
0.2 \%\end{array}$ & $\begin{array}{r}453 \\
1.4 \%\end{array}$ & $\begin{array}{l}1251 \\
3.9 \%\end{array}$ & $\begin{array}{r}85 \\
0.3 \%\end{array}$ & $\begin{array}{r}7835 \\
24.5 \%\end{array}$ & $\begin{array}{l}2453 \\
7.7 \%\end{array}$ & $\begin{array}{l}3138 \\
9.8 \%\end{array}$ & $\begin{array}{r}3656 \\
11.4 \%\end{array}$ & $\begin{array}{r}3480 \\
10.9 \%\end{array}$ & $\begin{array}{r}9580 \\
29.9 \%\end{array}$ & & \\
\hline
\end{tabular}


Table 4 - Models for trip-to-work distance

\begin{tabular}{|c|c|c|c|c|c|c|}
\hline & \multicolumn{4}{|c|}{ Standard models (OLS/logistic estimates) } & \multirow{2}{*}{\multicolumn{2}{|c|}{$\begin{array}{c}\text { Simultaneous two-equation } \\
\text { model }\end{array}$}} \\
\hline & \multicolumn{2}{|c|}{ Base Model } & \multicolumn{2}{|c|}{ Expanded model } & & \\
\hline & Coefficient & Std. Error & Coefficient & Std. Error & Coefficient & Std. Error \\
\hline Bridge & \multicolumn{2}{|l|}{ - } & $11,622.48$ & 117.78 & $12,774.79$ & 488.08 \\
\hline Number of Vehicles & $1,209.89$ & 80.98 & 241.50 & 67.02 & 189.09 & 70.44 \\
\hline People & 135.86 & 54.63 & -37.97 & 44.23 & -46.38 & 44.37 \\
\hline Male Dummy & $2,401.95$ & 127.71 & $1,485.46$ & 104.03 & $1,394.98$ & 110.59 \\
\hline Age & -23.59 & 5.50 & -30.84 & 4.45 & -30.12 & 4.46 \\
\hline Low Income Dummy & $-2,201.61$ & 176.87 & $-1,029.09$ & 143.44 & $-1,028.50$ & 143.38 \\
\hline Medium Income Dummy & 36.40 & 140.84 & -207.47 & $114.02^{* *}$ & -244.01 & $115.12^{* *}$ \\
\hline Full Time Dummy & $2,910.36$ & 209.25 & $1,324.83$ & 169.51 & $1,314.79$ & 169.50 \\
\hline AM Peak Dummy & -285.68 & 134.24 & -84.35 & 108.17 & -86.41 & 108.12 \\
\hline Number of daily trips & $-1,058.05$ & 44.18 & -554.43 & 35.81 & -555.27 & 35.80 \\
\hline Origin Park ${ }^{+}$ & - & & 483.99 & 687.55 & 476.81 & 687.20 \\
\hline Origin Big Box & - & & 671.07 & $401.18 *$ & 672.31 & 401.01* \\
\hline Origin Train & - & & $2,095.92$ & 400.24 & $2,096.07$ & 400.08 \\
\hline Origin Single Family & - & & $1,810.20$ & 156.71 & 1,807.35 & 156.64 \\
\hline Origin Highway & - & & 29.13 & 253.40 & 28.06 & 253.29 \\
\hline Origin Commercial Streets & - & & 824.34 & 350.65 & 826.72 & 350.52 \\
\hline Origin Waterfront & - & & $3,235.79$ & 398.88 & $3,235.73$ & 398.68 \\
\hline Origin Urban Mixed Use & - & & 1310.79 & 252.39 & $1,312.03$ & 252.30 \\
\hline Destination Isolated Sub ${ }^{++}$ & - & & -285.48 & 1120.78 & -288.08 & $1,120.32$ \\
\hline Destination Waterfront & - & & 912.46 & $461.92 * *$ & 910.36 & $461.70^{* *}$ \\
\hline Destination Mixed Use & - & & 535.05 & $300.19 *$ & 535.56 & $300.04 *$ \\
\hline Destination Office Park & - & & -195.32 & 993.23 & -195.83 & 992.80 \\
\hline Destination Suburb & - & & -200.51 & 209.53 & -200.61 & 209.43 \\
\hline Destination Big Box & - & & 314.41 & 254.09 & 315.27 & 253.97 \\
\hline Destination Train & - & & 1,118.31 & 220.21 & $1,118.16$ & 220.10 \\
\hline Destination Institutional & - & & $1,213.89$ & 224.45 & $1,213.21$ & 224.35 \\
\hline Destination Job Centre & - & & $1,415.08$ & 194.79 & $1,413.14$ & 194.70 \\
\hline Job_30 (in thousands) & - & & -3.43 & 0.16 & -3.43 & 0.16 \\
\hline work_30 (in thousands) & - & & 2.00 & 0.14 & 1.99 & 0.14 \\
\hline Constant & 11715.82 & 426.11 & $9,502.13$ & 437.50 & $9,271.36$ & 447.45 \\
\hline Bridge (binary model) & & & & & & \\
\hline Number of Vehicles & & & 0.23 & 0.01 & 0.14 & 0.01 \\
\hline With children & & & 0.13 & 0.04 & 0.09 & 0.02 \\
\hline Medium Income dummy & & & 0.14 & 0.02 & 0.09 & 0.01 \\
\hline Middle-age adult $^{+++}$ & & & 0.23 & 0.02 & 0.15 & 0.02 \\
\hline Male dummy & & & 0.35 & 0.02 & 0.22 & 0.01 \\
\hline Constant & & & -1.42 & 0.04 & -0.88 & 0.02 \\
\hline $\begin{array}{l}\text { No. Of observations = } \\
31,997\end{array}$ & $\mathrm{R}^{2}=$ & .06 & $\mathrm{R}^{2}$ & .40 & $\begin{array}{r}\rho=-0 . \\
\text { Likelihood ratic }\end{array}$ & $\begin{array}{l}\text { 0.03) } \\
\text { st: } \chi_{(1)}{ }^{2}=6.1^{* *}\end{array}$ \\
\hline
\end{tabular}

Variables in bold are significant at the $99 \%$ level, ** Significant at the $95 \%$ level * Significant at the $90 \%$ level

${ }^{+}$Reference category is (Origin) High Density Residential ++ Reference category is (Destination) High Density mixed use.

${ }^{+++}$between 25 and 45 years old. 